\title{
PENGEMBANGAN PERANGKAT ASESMEN AUTENTIK PADA TEMA MAKANAN SEHAT DAN BERGIZI KELAS IV SEKOLAH DASAR
}

\author{
Vicky Dwi Wicaksono \\ Fakultas Ilmu Pendidikan \\ Universitas Negeri Surabaya \\ vickywicaksono@unesa.ac.id
}

\begin{abstract}
Abstrak
Kurikulum 2013 ini mewajibkan setiap guru untuk menggunakan tema pada jenjang Sekolah Dasar (SD) atau Madrasah Ibtidaiyah (MI). Siswa dituntut menjadi orang yang aktif untuk memperoleh pengetahuan. Keterampilan proses yang dimiliki siswa selama pembelajaran, menentukan hasil belajar yang diperoleh. Asesmen autentik memberikan kesempatan luas pada siswa untuk menunjukkan apa yang telah mereka pelajari selama pembelajaran. Tujuan penelitian ini menghasilkan produk perangkat asesmen autentik pada tema Makanan Sehat dan Bergizi subtema Makananku Sehat dan Bergizi siswa kelas IV SD, serta mengetahui hasil uji validasi perangkat asesmen autentik pada tema Makanan Sehat dan Bergizi Subtema Makananku dan Bergizi siswa kelas IV MI melalui uji coba ahli, telaah guru, dan tanggapan siswa. Desain penelitian pengembangan yang digunakan ini adalah model pengembangan asesmen autentik $O$ ' Malley \& Pierce yakni (1) membangun sebuah tim; (2) menentukan tujuan dari asesmen autentik; (3) analisis konstruk; (4) melakukan pengembangan professional pada asesmen autentik; (5) mengkaji penelitian terdahulu mengenai asesmen autentik; (6) mengadaptasi asesmen yang ada atau mengembangkan yang baru; (7) mencoba asesmen; dan (8) revisi asesmen. Hasil uji coba ahli evaluasi pembelajaran mendapatkan $86,6 \%$ dan ahli pembelajaran tematik memperoleh skor 78,85\%. Hasil uji lapangan kepada guru dan siswa mengenai keefektifan, keterterapan, dan keterbacaan mendapatkan kategori sesuai.
\end{abstract}

Kata Kunci: Asesmen Autentik, Tema, Makanan Sehat dan Bergizi

\section{Pendahuluan}

Kurikulum 2013 ini mewajibkan setiap guru untuk menggunakan tema pada jenjang Sekolah Dasar (SD) atau Madrasah Ibtidaiyah (MI). Pembelajaran menggunakan tematik terpadu sesuai dengan Permendikbud No. 22 Tahun 2016 tentang Standar Proses Pendidikan Dasar dan Menengah. Implementasi Kurikulum 2013 menyediakan buku pegangan siswa dan guru, buku tersebut sesuai dengan peruntukannnya masing-masing.

Buku pegangan siswa "Makananku Sehat dan Bergizi Untuk SD/MI Kelas IV" berisi kegiatan antara lain Ayo Cari Tahu,
Ayo Belajar, Ayo Ceritakan, Ayo Bekerja Sama, Ayo Berlatih, Ayo Amati, Ayo Lakukan, Ayo Simpulkan, Ayo Renungkan, Ayo Kerjakan, Ayo Mencoba, Ayo Diskusikan, Ayo Bandingkan, Ayo Menulis, Ayo Temukan Jawabannya, Ayo Menaksir, Ayo Berkreasi, Ayo Analisis, Ayo Kelompokkan, Ayo Bernyanyi, Ayo Berpetualang, Tahukah Kamu, dan Belajar di Rumah.. Pembelajaran yang dilakukan siswa mencerminkan mata pelajaran Pendidikan Pancasila dan Kewarganegaraan, Bahasa Indonesia, Matematika, Seni Budaya dan Prakarya, dan PJOK pada kelas 1-3, 
sedangkan pada siswa kelas 4-6 ditambahkan mata pelajaran IPA dan IPS.

Setiap kegiatan dalam buku pegangan siswa merupakan proses belajar. Proses belajar menurut Sudjana (2009: 3) suatu kegiatan belajar mengajar yang dilakukan oleh siswa dan guru dalam mencapai tujuan-tujuan pengajaran. Proses belajar pada Kurikulum 2013 meningkatkan kompetensi sikap spiritual, sikap sosial, pengetahuan, dan keterampilan. Pada buku panduan guru bertolak belakang dengan buku pegangan siswa. Beberapa kegiatan asesmen proses belajar di buku pegangan siswa tidak tampak. Kegiatan proses belajar menentukan hasil belajar yang akan diperoleh siswa.

Hasil belajar (Purwanto, 2009: 46) adalah tingkat penguasaan yang dicapai oleh siswa dalam mengikuti proses belajar sesuai dengan tujuan pengajaran yang telah ditetapkan. Penguasaan tujuan pengajaran oleh siswa ditandai dengan meningkatnya kompetensi siswa.

Berdasarkan hasil angket yang diberikan kepada 20 siswa kelas IV Ngenep 5 pada hari Selasa 27 Februari 2018, ditemukan bahwa guru kelas IV cenderung menggunakan bentuk soal pilihan ganda dan esai untuk mengukur hasil belajar. Siswa mengungkapkan tes seperti pilihan ganda dan esai menyebabkan perasaan takut dan tegang dalam mengerjakannya. Bentuk soal pilihan ganda dan esai hanya mengukur kemampuan kognitif memahami, mengaplikasikan, menganalisis, dan mengevaluasi. Kemampuan kognitif mencipta tidak bisa dilakukan dengan soal pilihan ganda dan esai.

Proses mencipta (Lorin, dkk, 2010: 127) merupakan kemampuan kognitif yang paling tertinggi, meminta siswa membuat produk dengan pengalaman-pengalaman belajar sebelumnya. Hasil produk siswa berbentuk membuat hipotesis, mendesain, dan mengkonstruksi.

Hasil belajar berupa produk ditentukan sejauhmana siswa mengikuti proses belajar. Proses dan hasil belajar tidak bisa dilepaskan, setiap kegiatan siswa harus dilakukan asesmen dari waktu ke waktu. Asesmen autentik menurut Dauglas (2004: 13) adalah salah satu jenis asesmen yang menekankan pada proses belajar dan hasil belajar. Asesmen autentik mengacu pada rekaman sistematis pengamatan perkembangan dari waktu ke waktu oleh guru. Pengumpulan informasi yang dilakukan asesmen autentik tentang perkembangan dan pencapaian pembelajaran yang dilakukan oleh siswa, menggunakan berbagai macam teknik yang menunjukkan bahwa tujuan pembelajaran telah dikuasai. Asesmen autentik dilakukan dalam pembelajaran untuk menjamin objektivitas penilaian.

Asesmen autentik menurut Wiyono (2009: 42) mengungkapkan hal-hal yang benar-benar diketahui dan dapat dilakukan siswa. Siswa dituntut menjadi orang yang aktif untuk memperoleh pengetahuan. Keterampilan proses yang dimiliki siswa selama pembelajaran, menentukan hasil belajar yang diperoleh. Asesmen autentik memberikan kesempatan luas pada siswa untuk menunjukkan apa yang telah mereka pelajari selama pembelajaran. Elaine (2002: 165) menyatakan asesmen autentik membuat siswa sadar akan pentingnya proses belajar.

Asesmen autentik merupakan inovasi dalam bidang evaluasi pembelajaran. Asesmen autentik meliputi penekanan pada kemampuan nyata siswa, mengembangkan seluruh kemampuan siswa melalui kegiatan pembelajaran menurut paham 
konstruktivisme, dan tidak menggunakan sistem tes tradisional. Asesmen autentik mampu memberikan bukti langsung atas kemampuan siswa dalam pembelajaran.

Asesmen autentik belum banyak dikembangkan di Sekolah Dasar terutama pada pembelajaran tematik. Hasil penelitian terdahulu yang dilakukan oleh (1) Widi Puji Astuti (2012) dengan judul pengembangan instrument asesmen autentik berbasis literasi sains pada materi ekskresi. Penelitian ini menitikberatkan pada lietrasi sains. Hasil penelitian menunjukkan asesmen autentik menunjukan perubahan positif hasil belajar siswa, peningkatan indeks gain berada pada kisaran sedangm dan adanya pengaruh positif terhadap hasil belajar; (2) Fatimah Setiani (2011) dengan judul pengembangan asesmen alternatif dalam pembelajaran matematika dengan pendekatan realistik di Sekolah Penelitian ini berpusat pada pembelajaran PMRI yang menggunakan asesmen alternative. Hasil penelitian seluruh perangkat asesmen yang dihasilkan dapat meningkatkan kualitas proses dan hasil pembelajaran matematika yang cenderung meningkat. Berdasarkan hasil studi kepustakaan dan studi lapangan penggunaan asesmen autentik belum banyak diterapkan. Selama ini asesmen autentik sering digunakan pada mata pelajaran Bahasa Indonesia, Bahasa Inggris, Matematika dan IPA.

\section{Metode Penelitian}

Desain penelitian pengembangan yang digunakan ini adalah model pengembangan asesmen autentik O' Malley \& Pierce yang dimodifikasi. Langkahlangkah model pengembangan asesmen autentik (O' Malley \& Pierce, 1996: 17) yaitu: (1) membangun sebuah tim; (2) menentukan tujuan dari asesmen autentik; (3) analisis konstruk; (4) melakukan pengembangan professional pada asesmen autentik; (5) mengkaji penelitian terdahulu mengenai asesmen autentik; (6) mengadaptasi asesmen yang ada atau mengembangkan yang baru; (7) mencoba asesmen; dan (8) revisi asesmen. Pengembangan asesmen ini biasanya digunakan untuk mengembangkan Bahasa Inggris, akan tetapi tidak menutup kemungkinan untuk pengembangan yang lainnya.

Prosedur penelitian pengembangan yang dilakukan peneliti adalah model O'Malley \& Pierce yang dimodifikasi, hal ini diperlukan untuk mendapatkan prosedur pengembangan yang efektif. Penyusunan pengembangan asesmen autentik pada tema 9 (sembilan) Makanan Sehat dan Bergizi Kelas IV SD sub tema Makananku Sehat Bergizi melalui prosedur pengembangan sebagai berikut.

a. Pembentukan Tim

Pembentukan tim dilakukan dengan cara melakukan kerjasama antara peneliti dengan guru kelas di SD. Kerjasama tim dibutuhkan untuk mengecek kenyataan yang ada di lapangan dan kesesuaian teori yang ada.

b. Pengumpulan Informasi

Pengumpulan informasi dilakukan dengan cara memberi angket respon siswa, wawancara guru, hasil belajar siswa, dan administrasi siswa. Angket respon siswa dilakukan kepada siswa dengan memberikan beberapa pertanyaan mengenai cara guru memberikan ujian (evaluasi) kepada siswa. Pertanyaan dalam angket respon siswa berupa pertanyaan terbuka, agar diperoleh data yang menggambarkan keadaan sesungguhnya. Ada dua data yang diperoleh dalam angket respon siswa ini, yaitu mengenai evaluasi yang digunakan guru (jenis ujian yang digunakan) dan menggambarkan karakteristik siswa.

c. Menentukan Tujuan Asesmen

Tujuan asesmen diperoleh melalui studi kepustakaan, analisis standar isi, standar proses, kompetensi dasar, struktur kurikulum SD, dan penelitian terdahulu. Hal ini dilakukan untuk memperoleh data 
secara teori mengenai produk yang dikembangkan.

\section{d. Analisis Konstruk}

Analisis konstruk meliputi menyusun kisikisi asesmen dan draft instrumen. Kisikisi asesmen terdiri dari komponen identitas, jenis pendidikan dan jenjang pendidikan, tema, tahun ajaran, kompetensi inti, kompetensi dasar, indikator, dan tujuan pembelajaran. Pada draft instrumen mengembangkan asesmen awal.

e. Mengembangkan Asesmen

Mengembangkan asesmen merupakan langkah menentukan bentuk asesmen autentik. Bentuk asesmen yang digunakan dalam pengembangan ini adalah asesmen portofolio untuk proses belajar dan asesmen kinerja untuk hasil belajar.

f. Validasi Ahli

Validasi ahli merupakan kegiatan untuk mengumpulkan data validitas instrumen kepada para ahli. Uji ahli dalam pengembangan asesmen dilakukan kepada uji ahli evaluasi pembelajaran, uji ahli pembelajaran tematik, dan uji psikologi pendidikan. Tujuan melakukan validasi ahli untuk menguji kelayakan produk dihadapan para ahli.

g. Mencoba Asesmen

Hasil uji ahli asesmen yang dikembangkan dilakukan uji coba, untuk mengetahui tanggapan siswa dan tanggapan guru. Hasil uji coba untuk mengetahui tujuan asesmen. Hasil akhir uji coba asesmen digunakan untuk mengetahui keefektifan produk.

h. Revisi Asesmen

Hasil uji coba asesmen digunakan sebagai pertimbangan untuk merivisi produk yang dikembangkan. Hasil revisi pada langkah ini ialah hasil akhir produk pengembangan asesmen.

Uji coba produk adalah hal wajib dalam pengembangan produk asesmen autentik. Berikut tindakan uji coba produk meliputi. a. Desain Uji Coba

Desain uji coba yaitu menguji produk pengembangan asesmen autentik. Pengembangan perangkat asesmen yang telah dibuat ditelaah lebih mendalam kepada anggota partisipan parsial dan partisipan penuh. Partisipan parsial adalah para ahli evaluasi pembelajaran, psikologi pendidikan dan ahli pembelajaran tematik, sedangkan partisipan penuh ditujukan kepada guru dan siswa kelas IV SD. Hasil desain uji coba menentukan hasil dari pengembangan perangkat asesmen autentik.

b. Subjek Coba

Subjek coba pengembangan produk penelitian dan pegembangan ini adalah ahli evaluasi pembelajaran, ahli pembelajaran tematik, ahli psikologi pendidikan, guru kelas IV, dan siswa kelas IV SD. Subjek coba yang dipilih memiliki kualifikasi sebagai berikut.

1) Ahli evaluasi pembelajaran harus dengan kriteria (a) memiliki latar belakang pendidikan dari jurusan evaluasi pendidikan atau pendidikan matematika atau pendidikan dasar minimal magister, dan (b) memiliki pengalaman mengenai evaluasi atau statistik pendidikan minimal 3 tahun.

2) Ahli pembelajaran tematik harus dengan kriteria (a) memiliki latar belakang pendidikan dasar minimal magister, dan (b) memiliki pengalaman mengenai tematik minimal 3 tahun.

3) Guru kelas IV SD dengan kriteria (a) memiliki latar belakang Pendidikan Guru Sekolah Dasar (PGSD) minimal strata satu, (b) pengalaman mengajar khusus di kelas IV selama 3 tahun, (c) memahami karakteristik siswa, dan (d) penguasaan kelas baik.

4) Siswa kelas IV SD harus dengan kriteria (a) siswa sedang berada di semester 2 (dua), (b) memiliki pengetahuan dasar (membaca, menulis, dan menghitung), dan (c) sedang atau belum menggunakan Kurikulum 2013 edisi revisi 2014. 


\section{c. Jenis Data}

Jenis data dalam penilitian ini adalah berupa data kualitatif dan data kuantitatif. Data kualitatif diperoleh dari hasil studi pendahuluan, hasil dari uji ahli, telaah guru dan tanggapan siswa. Data kuantitatif yaitu informasi yang diperoleh dari angket dan rubrik penilaian uji ahli, telaah guru, tanggapan siswa, dan uji lapangan yang dirubah dalam bentuk kuantitatif dan dijelaskan secara kualitatif. Data dalam penelitian meliputi data kevalidan, keefektifan, keterterapan, dan keterbacaan. Data kevalidan diperoleh dari vadilasi uji ahli, sedangakan data keefektifan, keterterapan, dan keterbacaan diperoleh dari guru dan siswa Kelas IV SD.

d. Instrumen Pengumpulan data

Instrumen pengumpul data yang digunakan sebagai alat penjaring data terdiri atas instrumen utama dan instrumen penunjang. Instrumen utama adalah peneliti. Sedangkan, instrumen penunjangnya adalah dengan teknik angket, wawancara, observasi, dan dokumentasi. Instrumen penunjang memuat aspek kevalidan, keterbacaan, keterterapan, dan keefektifan. Teknik angket digunakan untuk mengumpulkan data analisis kebutuhan siswa, karakteristik siswa, evaluasi ahli, dan untuk evaluasi siswa. Teknik wawancara dengan daftar pertanyaan yang digunakan untuk mevalidasi dan mengklarifikasi hasil angket yang diberikan. Teknik observasi digunakan untuk melihat pelaksanaan asesmen autentik di kelas. Pedoman observasi sebagai dasar pengamatan yang dilakukan di kelas. Teknik dokumentasi digunakan untuk mengumpulkan data berupa kurikulum pembelajaran dan informasi-informasi lain untuk keperluan karakterisitik siswa. Berikut ini merupakan data yang akan diperoleh dalam pengembangan.

Tabel 1. Data yang diperoleh

\begin{tabular}{|l|c|c|}
\hline \multicolumn{1}{|c|}{ Data } & $\begin{array}{c}\text { Instrum } \\
\text { en }\end{array}$ & Data yang Diamati \\
\hline Validitas & Angket & $\bullet$ Kevalidan RPP dan \\
\hline
\end{tabular}

\begin{tabular}{|c|c|c|}
\hline \multirow[t]{2}{*}{ produk } & validasi & $\begin{array}{l}\text { Instrumen } \\
\text { pengembangan }\end{array}$ \\
\hline & $\begin{array}{l}\text { Angket } \\
\text { validasi }\end{array}$ & $\begin{array}{l}\text { - Kevalidan RPP dan } \\
\text { Instrumen } \\
\text { pengembangan }\end{array}$ \\
\hline Keefektifan & Angket & $\begin{array}{l}\text { - Ketercapaian } \\
\text { tujuan } \\
\text { pembelajaran } \\
\text { - Proses belajar } \\
\text { - Hasil belajar } \\
\text { - Ketuntasan belajar } \\
\text { - Rasa cemas dalam } \\
\text { proses dan hasil } \\
\text { belajar }\end{array}$ \\
\hline Keterterapan & Angket & $\begin{array}{l}\text { - Kemudahan } \\
\text { menggunakan } \\
\text { instrumen } \\
\text { pengembangan } \\
\text { - Waktu pelaksanaan }\end{array}$ \\
\hline Keterbacaan & Angket & $\begin{array}{l}\text { - Petunjuk mudah } \\
\text { dipahami }\end{array}$ \\
\hline
\end{tabular}

e. Teknik Analisis Data

Teknik yang digunakan untuk menganalisis data dalam penelitian asesmen autentik ada 2 (dua) macam yaitu analisis deskriptif kualitatif dan statistik deskriptif. Analisis deskriptif kualitatif yang digunakan dalam penelitian ini yakni wawancara, dokumentasi, lembar validasi, dan angket.

Analisis statistik deskriptif digunakan pada hasil validasi ahli menggunakan pencapaian konversi skala 5, yakni.

Tabel 2. Konversi tingkat pencapaian

\begin{tabular}{|c|c|l|l|}
\hline Skala & $\begin{array}{l}\text { Tingkat } \\
\text { Pencapaian }\end{array}$ & Kualifikasi & Keterangan \\
\hline 5 & $90 \%-100 \%$ & Sangat Valid & $\begin{array}{l}\text { Tidak perlu } \\
\text { revisi }\end{array}$ \\
\hline 4 & $75 \%-89 \%$ & Valid & $\begin{array}{l}\text { Tidak perlu } \\
\text { revisi }\end{array}$ \\
\hline 3 & $65 \%-74 \%$ & Cukup Valid & Revisi \\
\hline 2 & $55 \%-64 \%$ & Kurang Valid & Revisi \\
\hline 1 & $0-54 \%$ & Tidak Valid & Revisi \\
\hline
\end{tabular}

Pengukuran keefektifan, keterterapan, dan keterbacaan menggunakan angket siswa, dan angket guru dengan kriteria kesesuaian dibagi menjadi menjadi 3 sub interval yang sama, yaitu $1 \leq \mathrm{x}<2, \quad 2 \leq \mathrm{x}<4,4 \leq \mathrm{x}<5$. Atas dasar itu, maka kriteria kesesuaian produk ini ditetapkan sebagai berikut:

- Sesuai, jika $4 \leq \mathrm{x}<5$

- Cukup sesuai, jika $2 \leq \mathrm{x}<4$

- Tidak sesuai, jika $1 \leq \mathrm{x}<2$ 
Indikator sesuai merupakan capaian yang diharapkan dalam pengembangan perengkar asesmen autentik. Produk pengembangan pada indikator cukup sesuai dan tidak sesuai dilakukan revisi untuk mencapai indikator sesuai.

\section{Hasil dan Pembahasan}

Perangkat asesmen autentik merupakan hasil dalam penelitian yang dilakukan. Pengembangan diawali dengan membuat storyboard, yakni merupakan rencana atau skenario pembuatan produk. Produk yang dikembangkan diperoleh melalui identifikasi kurikulum 2013 edisi revisi 2014.

Hasil yang diperoleh melalui storyboard dibuatakan rancangan produk awal. Produk yang dihasilkan terdiri dari lembar kegiatan siswa dan lembar kegiatan guru. Lembar kegiatan guru berisi petunjuk penggunaan, Rencana Pelaksanaan Pembelajaran (RPP), dan penjelasan Lembar Kegiatan Siswa.

Lembar kegiatan siswa berisi petunjuk penggunaan, kegiatan, penilaian portofolio dan kinerja. Kegiatan inti pada lembar kegiatan siswa terdiri dari ingat aku, mari bertanya, carilah aku, mari berdiskusi, mari berkarya, mari berimajinasi, dan mari menyelesaikan masalah. Setiap kegiatan mencerminkan penilaian portofolio dan kinerja.

Paparan data yang diperoleh melalui validitas produk perangkat asesmen autentik yang isinya penilaian portofolio dan kinerja. Hasil dari ahli evaluasi pembelajaran diperoleh nilai $86,6 \%$ yaitu sangat sesuai atau valid, sehingga tidak perlu diperlukan untuk melakukan revisi yang ada. Saran validasi pada perangkat asesmen yakni 1) petunjuk penggunaan asesmen oleh siswa diperlukan pembenahan; 2) perlu ditambahkan kesimpulan penilaian pada asesmen autentik.

Penarikan kesimpulan merupakan bagian pada asesmen autentik. Penilaian portofolio Sukanti (2010: 39) bertujuan untuk mengukur kemampuan peserta didik dalam membangun dan merefleksi suatu tugas atau karya melalui pengumpulan bahan-bahan yang relevan, sehingga hasil pekerjaan tersebut dapat dinilai dan dikomentari oleh guru dalam periode tertentu. Penilaian secara mandiri merupakan capaian yang harus dilakukan oleh siswa.
Ahli
pembelajaran
tematik melakukan validasi pada produk perangkat asesmen autentik. Validasi yang dilakukan pada pembelajaran tematik dan RPP. Hasil pembelajaran ahli pembelajaran IPS yakni $80 \%$ artinya sesuai atau valid. Kevalidan RPP mencapai $77,7 \%$ yang artinya sesuai atau valid dan tidak dipelukan revisi yang besar. Pada "mari berkarya" perlu diperjelas pada kegiatannya. Berikut ini deskripsi revisi produk ke-1 hasil masukan dari ahli evaluasi dan pembelajaran tematik.

Tabel 3. Hasil Revisi Produk ke-1

\begin{tabular}{|c|c|c|}
\hline $\begin{array}{l}\text { Bagian yang } \\
\text { Direvisi }\end{array}$ & Sebelum Revisi & Hasil Revisi \\
\hline RPP & $\begin{array}{l}\text { - Kegiatan } \\
\text { sisiwa pada } \\
\text { "mari } \\
\text { bekarya" } \\
\text { perlu } \\
\text { disederhankan }\end{array}$ & $\begin{array}{l}\text { - Perubahan } \\
\text { kegiatan } \\
\text { pada "mari } \\
\text { bekarya" }\end{array}$ \\
\hline $\begin{array}{l}\text { Asesmen } \\
\text { Protofolio }\end{array}$ & $\begin{array}{l}\text { - Petunjuk } \\
\text { penggunaan } \\
\text { masih } \\
\text { sederhana }\end{array}$ & $\begin{array}{l}\text { - Petunjuk } \\
\text { dilengkapi } \\
\text { contoh } \\
\text { penggunaan } \\
\text { untuk yang } \\
\text { digunakan } \\
\text { oleh siswa } \\
\end{array}$ \\
\hline $\begin{array}{l}\text { Asesmen } \\
\text { Kinerja }\end{array}$ & $\begin{array}{l}\text { Rubrik } \\
\text { penilaian } \\
\text { diperlukan } \\
\text { kesimpulan } \\
\text { penilaian } \\
\end{array}$ & $\begin{array}{l}\text { - Penambahan } \\
\text { rubrik } \\
\text { kesimpulan } \\
\text { penilaian }\end{array}$ \\
\hline
\end{tabular}

Produk hasil revisi dari ahli evaluasi dan pembelajaran tematik digunakan oleh guru dan siswa untuk memperoleh data uji coba lapangan berkaitan dengan keefektifan, keterterapan, keterbacaan, proses dan hasil belajar.

Keefektifan penggunaan perangkat asesmen autentik ditentukan ketercapaian tujuan pembelajaran, rasa cemas dalam proses, hasil dan proses belajar. Penilaian yang diberikan oleh guru dan siswa pada ketercapaian tujuan pembelajaran dan rasa cemas dalam proses mendapatkan skor 4,25. Hasil penilaian skor 
tersebut sesuai pada skala $4 \leq \mathrm{x}<5$. Penilaian kinerja menurut Lestari (2015: 690) penilaian kinerja untuk menilai dimensi proses dan hasil belajar siswa yang tidak tergali melalui tes, sehingga tidak menyebabkan rasa cemas pada siswa.

Hasil belajar rata-rata siswa mendapatkan 78,6 dengan ketuntasan belajar mencapai $75 \%$, sedangkan pada proses belajar mendapatkan skor rata-rata 79,3 dimana skor tersebut diperoleh dari hasil penilaian portofolio yang telah dilakukan oleh siswa. Guru memberi masukan untuk menyederhakan penilaian portofolio. Siswa memberikan masukan pada angket yang diberikan mengenai urutan portofolio.

Keterterapan berkaitan dengan Kemudahan menggunakan instrumen pengembangan dan waktu pelaksanaan. Hasil yang diberikan oleh guru sebesar 4,25. Skor yang diberikan oleh siswa yakni 4 . Guru dan siswa dapat menggunakan asesmen autentik, penilaian yang diberikan termasuk kategori sesuai dengan interval $4 \leq \mathrm{x}<5$. Catatan dari guru yakni waktu yang dibutuhkan dalam penyelesaikan dalam kegiatan perlu dituliskan pada setiap bagian pada kegiatan di sub tema, sehingga ada skala priotitas aktivitas belajar yang dilaksanakan

Keterbacaan pada perangkat asesmen autentik mendapatkan skor 4 dari guru dan siswa, jika berada pada skala $4 \leq \mathrm{x}<5$ maka asesmen ditetapkan sesuai. Petunjuk untuk guru dan siswa dibedakan dengan menekankan pada contoh yang akan dilaksanakan ketika melakukan penilaian. Berikut ini hasil revisi produk ke-2.

Tabel 4. Hasil Revisi Produk ke-2

\begin{tabular}{|l|l|l|}
\hline Komponen & Sebelum Revisi & Hasil Revisi \\
\hline Keefektifan & • Penilaian & • Penilain \\
& portofolio & portofolio \\
& untuk guru & untuk guru \\
& dan siswa & dan siswa \\
& dibuat & dibuatkan \\
& sederhana & tabel \\
& & penilaian \\
& - Panduan & Pembuatan \\
& pengumpulan & daftar \\
& portofolio & panduan \\
& & portofolio \\
\hline
\end{tabular}

\begin{tabular}{|l|l|l|}
\hline Keterterapan & $\begin{array}{l}\text { • Tidak adanya } \\
\text { pembagian } \\
\text { waktu pada } \\
\text { lembar } \\
\text { kegiatan guru }\end{array}$ & $\begin{array}{l}\text { Lembar } \\
\text { kegiatan } \\
\text { guru } \\
\text { ditambahkan } \\
\text { waktu } \\
\text { pelaksanaan }\end{array}$ \\
\hline Keterbacaan & • Petunjuk & $\bullet$ Petunjuk \\
& penggunaan & lembar \\
asesmen & kegiatan \\
& autentik perlu & guru dan \\
& siswa \\
& disertai & disederhanak \\
& contoh & kalimatnya \\
& & dan disertai \\
& & contoh \\
\hline
\end{tabular}

\section{Kesimpulan Simpulan}

Pengembangan perangkat asesmen autentik dilakukan dengan melalui uji coba ahli evaluasi pembelajaran mendapatkan $86,6 \%$ dan ahli pembelajaran tematik memperoleh skor $78,85 \%$. Hasil uji lapangan kepada guru dan siswa mengenai keefektifan, keterterapan, dan keterbacaan mendapatkan kategori sesuai.

Hasil produk perangkat asesmen atutentik yang dikembangkan memiliki kelebihan dan kelemahan dalam pelaksanaan. Kelebihan produk: 1) siswa dapat belajar mandiri dan menilai diri sendiri, sehingga antusias dalam pembelajaran; 2) menumbuhkan nilai kejujuran pada siswa; dan 3) guru sebagai fasilitator dalam pembelajaran. Selain itu, kelemahan produk sebagai berikut: 1) pelaksanaan asesmen autentik membutuhkan waktu yang lama; 2) pengumpulan portofolio membebani siswa jika dibawa pulan ke rumah.

\section{Saran}

Produk yang dikembangkan memiliki kelemahan berkaitan dengan waktu pelaksanaan, diperlukan meminimalisir kelemahan yang akan dicapai seperti membuat perencanaan yang matang dan tepat. Selain itu produk hanya diujicobakan pada satu sekolah, sehingga bisa dilakukan diseminasi perangkat asesemen autentik kepada sekolah lain untuk mendapatkan produk yang berkualitas. 


\section{Daftar Acuan}

\section{Buku}

Elaine B Johnson. 2002 Contextual Teaching and Learning: What it is and why it's here to stay. USA: Corwin Press Inc.

H. Dauglas Brown. 2004. Language Assessment: Principples and Classroom Practice. New York: Pearson Education Inc.

Kementerian Pendidikan dan Kebudayaan. 2014. Buku Siswa Makananku Sehat dan Bergizi Untuk SD/MI Kelas IV . Jakarta: Pusat Kurikulum dan Perbukuan Balitbang Kemdikbud.

Lorin W. Anderson dan David R. Krathwohl. 2010. Kerangka Landasan untuk Pembelajaran, Pengajaran, dan Asesmen Revisi Taksonomi Pendidikan Bloom. Yogyakarta: Pustaka Belajar.

Nana Sudjana. 2009. Penilaian Hasil Proses Belajar Mengajar. Bandung: Remaja Rosdakarya.

O’Malley, J.M. \& Pierce, L.V. 1996. Authentic Assessment for English Language Learners Protical
Approach for Teacher. USA: Addison-Wesley Publishing.

Purwanto. 2014. Evaluasi Hasil Belajar. Yogyakarta: Pustaka Belajar.

Wiyono, Bambang, dan Sunarni. 2009. Evaluasi Program Pendidikan dan Pembelajaran. Malang: Fakultas Ilmu Pendidikan Universitas Negeri Malang.

\section{Jurnal}

Gusti Ayu Putu Tiana Lestari, Noor Fadiawati, dan Lisa Tania. 2015. Pengembangan Instrumen Asesmen Kinerja pada Praktikum Pemisahan Campuran. Jurnal Pendidikan dan Pembelajaran Kimia. Volume 4. Nomor 2: 680-692.

Sukanti. 2010. Pemanfaatan Penilaian Portofolio dalam Meningkatkan Hasil Belajar Asuransi. Jurnal Pendidikan Akuntansi Indonesia. Volume VIII. Nomor 2: 33-40. 